Обзорная статья

УДК 541.64: 539.199

DOI 10.18101/2306-2363-2021-1-5-27

\title{
ЭФФЕКТ ПЛАСТИЧНОСТИ СТЕКОЛ В МОДЕЛИ ДЕЛОКАЛИЗОВАННЫХ АТОМОВ
}

\author{
(C) Сандитов Дандар Сангадиевич \\ доктор физико-математических наук, профессор \\ Бурятский государственный университет имени Доржи Банзарова \\ 670000, Улан-Удэ, ул. Смолина, 24a \\ Институт физического материаловедения СО РАН \\ 670047, Улан-Удэ, ул. Сахьяновой, 6 \\ sanditov@bsu.ru
}

\begin{abstract}
Аннотация. У неорганических стекол, аморфных органических полимеров и массивных металлических аморфных сплавов (металлических стекол) обнаруживается остаточная деформация, которая сохраняется сколь угодно долго при $20^{\circ} \mathrm{C}$. Однако при нагревании ниже температуры стеклования и вблизи нее данная деформация релаксирует практически до исчезновения. Тем не менее, как правило, для нее используется термин «пластическая деформация». Природа эффекта пластичности стекол остается не совсем ясной, до конца нерешенной задачей. В целом обзор посвящен обсуждению основных закономерностей и природы пластической деформации стеклообразных твердых тел и ее термостимулированной релаксации. Рассмотрены различные варианты интерпретации. Механизм и природа данного явления подробно обсуждаются в рамках модели делокализованных атомов, развиваемой в Бурятском государственном университете имени Доржи Банзарова и в Институте физического материаловедения СО РАН.

Ключевые слова: пластичность стекол, термостимулированная релаксация, стеклование, микротвердость, делокализация атома, компьютерное моделирование, наноиндентирование, микродеформация стекол.
\end{abstract}

Для цитирования: Сандитов Д. С. Эффект пластичности стекол в модели делокализованных атомов // Вестник Бурятского государственного университета. Химия. Физика. 2021. Вып. 1. С. 5-27.

\section{1. Введение}

Природа деформации стеклообразных твердых тел на протяжении многих лет является предметом всесторонних исследований. Интерес к этой проблеме обусловлен прежде всего широким применением на практике различных классов стекол и в связи с обнаружением у них значительной остаточной деформации (пластичности) [1-5].

Эффект пластичности неорганических стекол был обнаружен, по-видимому, Гелафом Г. и Томасом И. [1] в 1926 г. при микровдавливании силикатного стекла алмазной пирамидкой, а систематически был исследован впервые Бриджменом П. и Сименом И. [2]. Опыты показали, что у неорганических стекол при $20^{\circ} \mathrm{C}$ наблюдаются большие неупругие остаточные деформации, если механическое внешнее напряжение превышает некоторый порог $\sigma_{y}$, который для силикатных стекол по порядку величины совпадает с микротвердостью по Виккерсу $H_{V}$. Та- 
ким образом, при $\sigma>\sigma_{y}$ обнаруживается остаточная деформация стекол, которая сохраняется неопределенно долго (эффект пластичности стекол).

Однако примечательно то обстоятельство, что при нагревании ниже температуры стеклования $T_{g}$ и вблизи нее данная деформация релаксирует практически до исчезновения [2]. Следовательно, она оказывается на самом деле замороженной обратимой деформацией. Тем не менее, как принято в научной литератуpe, будем пользоваться термином «пластическая» и величину $\sigma_{y}$ будем называть пределом текучести.

Аналогичная обратимая замороженная (пластическая) деформация наблюдается у аморфных органических полимеров в стеклообразном состоянии (старые названия: «холодное течение», «вынужденно-эластическая деформация») [3, 4]. У массивных металлических стекол также обнаружены замороженная деформация и ее термостимулированная релаксация, основные закономерности которых фактически такие же, как и у стеклообразных органических полимеров и неорганических стекол [5]. Как видим, данное явление носит универсальный характер. Замороженная деформация стекол и ее термостимулированная релаксация по внешним проявлениям напоминают пластическую деформацию кристаллов и ее последействие. Однако из опытных данных следует, что пластичность стекол по природе принципиально отличается от пластичности кристаллов.

Настоящий обзор посвящен рассмотрению основных закономерностей и природы пластической деформации стеклообразных твердых тел и ее термостимулированной релаксации. При этом проводится сравнение этой деформации с размягчением стекла - с процессом, обратным стеклованию, что позволяет получить определенную информацию как о пластической деформации стекол, так и о переходе жидкость - стекло. Установлено, что существует определенная взаимосвязь между размягчением стекла и пластической деформацией стекол. Так, например, у ряда аморфных полимеров и неорганических стекол обнаружена линейная корреляция между пределом текучести $\sigma_{y}$ и температурой стеклования $T_{g}$ (температурой размягчения). Основные закономерности как стеклования, так и пластической деформации у аморфных веществ удовлетворительно описываются в рамках одной модели - модели делокализованных атомов, развиваемой в Бурятском государственном университете [6-10].

Как и в случае универсальности эффекта пластичности стекол, основные закономерности процесса стеклования в качественном отношении оказываются также универсальными для различных аморфных веществ независимо от их природы. Об этом свидетельствует наличие универсальных уравнений и правил в области стеклования [11-15].

Особенность обзора заключается в том, что, во-первых, эффект пластичности стекол рассматривается в тесной связи со стеклованием расплава. Во-вторых, уделено особое внимание совместному рассмотрению с единых позиций различных классов стеклообразных систем: неорганических стекол, аморфных органических полимеров, металлических аморфных сплавов. Кроме того, в-третьих, предлагается развитие универсальной модели аморфных веществ.

В обзоре кратко анализируются различные подходы к интерпретации пластической деформации стекол $[10,11,16-27]$. Более подробно рассматривается применение указанной выше модели. 
Насколько нам известно, в научной литературе нет подобного обзора эффекта пластичности стекол.

\section{2. Эффект пластичности неорганических стекол}

Бриджмен и Симон [2] установили, что при всестороннем, а также при одноосном сжатии стеклообразного борного ангидрида в твердом состоянии ниже температуры стеклования $T_{g} \approx 250^{\circ} \mathrm{C}$ наблюдается остаточная неупругая деформация, которая после разгрузки сохраняется в течение неопределенно долгого времени. Однако, при нагревании неупруго деформированного стекла в интервале $20-100^{\circ} \mathrm{C}$ восстанавливается его первоначальное исходное состояние. Следовательно, данная деформация оказывается не остаточной, а замороженной обратимой деформацией.

Они оценили энергию активации процесса термостимулированного возврата первоначального состояния стеклообразного борного ангидрида в указанном интервале температур по соотношению

$$
U=R\left(\frac{1}{T_{1}}-\frac{1}{T_{2}}\right)^{-1} \ln \frac{\mathrm{v}_{2}}{\mathrm{v}_{1}}(2.1)
$$

где $R$ - газовая постоянная, $\mathrm{v}_{1}$ и $\mathrm{v}_{2}$ - начальные скорости уменьшения остаточной деформации при температурах $T_{1}$ и $T_{2}$. Для энергии активации было получено удивительно низкое значение: $U=5.5$ кДж/моль. Хотя, как заметили авторы, эта оценка является приближенной, малая величина $U$ указала на необычную природу пластичности стекол.

После опытов Бриджмена и Симона эффект пластичности неорганических стекол изучался многими исследователями [28-32]. Более подробные систематические измерения в этом направлении провел Маккензи [31, 32], который показал, что пластичность стекол проявляется как при одноосном, так и при всестороннем сжатии, при микровдавливании алмазной пирамидки, при растяжении тонкой стеклянной нити (волокна).

Таким образом, если механическое внешнее напряжение превышает некоторый порог - предел текучести $\sigma_{y}$, происходит пластическая деформация стекол, которая при $20^{\circ} \mathrm{C}$ сохраняется сколь угодно долго. Однако, при нагревании ниже температуры стеклования $T_{g}$ и вблизи нее она релаксирует до исчезновения.

У силикатных стекол предел текучести составляет около

$$
\sigma_{\mathrm{y}} \approx 500 \mathrm{\kappa г \textrm {c }} / \mathrm{Mм}^{2}\left(5 \cdot 10^{4} \text { атм }\right),(2.2)
$$

что по порядку величины совпадает с микротвердостью по Виккерсу $H_{V}$. У этих стекол температурная зависимость скорости обсуждаемой деформации и скорости ее термостимулированной релаксации является экспоненциальной и их энергия активации примерно равна

$$
\Delta \mathrm{U} \approx 20 \text { кДж/моль, (2.3) }
$$

что резко отличается от энергии активации процесса вязкого течения ( 400 кДж/моль) и диффузии иона кислорода ( 250 кДж/моль) в силикатных стеклах. Следовательно, пластическая деформация и ее термостимулированная релаксация относятся к низкоактивационным релаксационным процессам. 


\section{3. Исследование пластичности стекол методом наноиндентирования}

При вдавливании четырехгранной алмазной пирамидки Виккерса в силикатное стекло при $20^{\circ} \mathrm{C}$ образуется пластическая лунка - микроотпечаток (рис. 3.1 , вид сверху). При этом микротвердость по Виккерсу $H_{V}$ у силикатных, германатных и других неорганических стекол совпадает с пределом текучести $H_{V} \approx \sigma_{y}$, выше которого наблюдается пластическая деформация [33, 34].

Как и следовало ожидать, при нагревании (ниже $T_{g}$ ) микроотпечаток уменьшается - наблюдается релаксация пластической деформации (рис. 3.1). Энергия активации этого процесса у силикатных стекол составляет 20 кДж/моль [11], что совпадает с энергией активации уплотнения и разуплотнения силикатных стекол при сжатии (2.3).

При внедрении в стекло заостренного индентора напряженное состояние локализуется в достаточно малом микрообъеме, линейные размеры которого меньше среднего расстояния между дефектами. Поэтому на результат измерения микротвердости не влияют дефекты (поверхностные микротрещины) [11].

Было показано [35-38], что под индентором возникает локальная деформация сдвига и что микротвердость $H_{V}$, рассматриваемая как среднее нормальное напряжение, на самом деле определяется максимальным касательным (тангенциальным) напряжением и служит характеристикой сопротивления материала сдвигу.
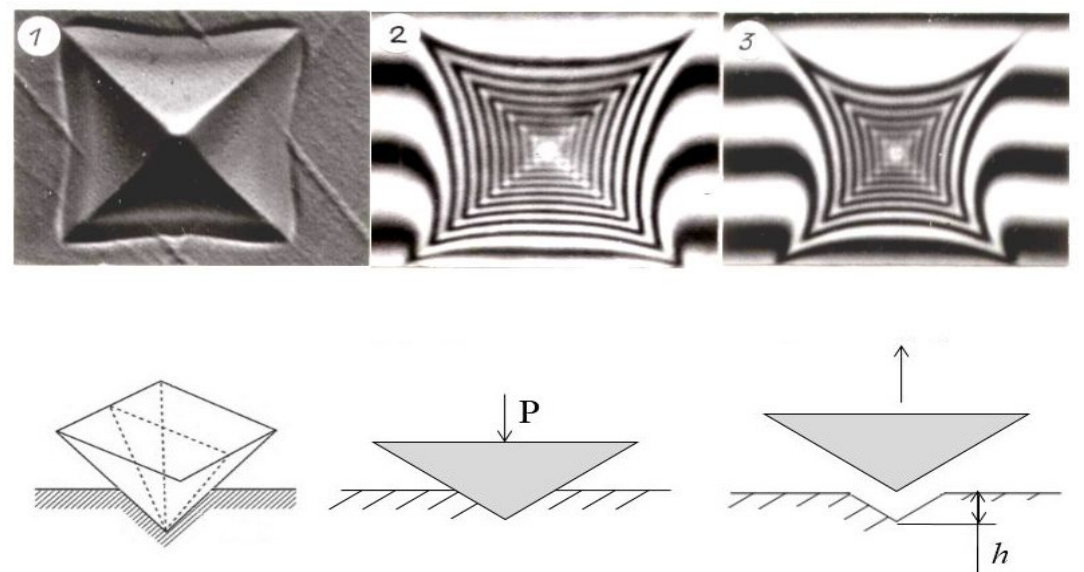

Рис. 3.1. Микроотпечатки Виккерса на листовом силикатном стекле: $1-$ при $T=20^{\circ} \mathrm{C}$;

2, 3 - виды в интерференционном микроскопе после нагрева, соответственно при $T=100^{\circ} \mathrm{C}, T=450^{\circ} \mathrm{C}$ в течение 10 мин; $P=150$ г., $T_{g}=620^{\circ} \mathrm{C}$.

В серии работ $[11,39-56]$ исследована кинетика термостимулированного восстановления микроотпечатков Виккерса и микроканавок на листовом силикатном стекле.

\section{4. Пластичность стеклообразных полимеров}

В первой половине XX века у аморфных органических полимеров в стеклообразном состоянии выше некоторого предельного механического напряжения $\sigma_{\mathrm{y}}$ была обнаружена большая остаточная деформация, которая получила название 
«холодное течение». Александровым, Лазуркиным и Фогельсоном были проведены первые систематические исследования $[3,4,57]$. Оказалось, что пластически деформированные стеклообразные аморфные полимеры при термостимулировании (нагревании) возвращаются к исходному недеформированному состоянию. Таким образом, было установлено, что «холодное течение» представляет собой не остаточную деформацию, а замороженную обратимую деформацию полимерных стекол.

Чтобы подчеркнуть принципиальное различие в механизмах возникновения больших остаточных деформаций в стеклообразных полимерах и металлах, будущий академик (Председатель Президиума АН СССР в 1980-1990-ые годы) Александров А.П. в 1945 г. предложил термин «вынужденно-эластическая де-

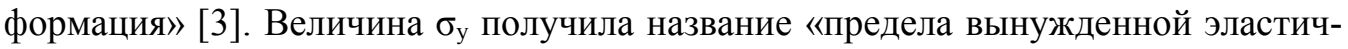
ности». Было развито представление, что переход цепных полимерных макромолекул из одного локального равновесного состояния в другое становится возможным лишь при значительном вынуждающем действии внешних напряжений. В свою очередь вынужденная высокоэластическая деформация после снятия напряжения остается фиксированной, так как тепловое движение при низких температурах оказывается ослабленным и не способно вернуть громоздкие макромолекулы к первоначальной конфигурации. Лишь при нагревании возникает необходимая подвижность макромолекул и деформация полностью самопроизвольно восстанавливается (исчезает) [3, 57].

В настоящее время несостоятельность такой «полимерной» концепции стала очевидной [58-64], ибо такие же большие остаточные деформации наблюдаются у низкомолекулярных органических и неорганических стекол, даже у металлических стекол, где нет никаких громоздких макромолекул.

Стеклообразные органические полимеры являются типичными представителями неупорядоченных некристаллических твердых тел и имеют такие же физико-механические характеристики, как и у всех стеклообразных систем. Поэтому следует ожидать, что природа замороженной обратимой деформации должна быть одинаковой как у высокомолекулярных, так и у низкомолекулярных стекол.

\section{5. Пластическая деформация массивных металлических стекол}

Металлические стекла (МС) получают сверхбыстрой закалкой (резким охлаждением) расплава металла, поэтому они являются сильно неравновесными структурами. Удивительно то, что они оказались достаточно устойчивыми системами. Начиная с 1970-х годов и в течение последующих примерно 30 лет МС получали в виде ленты толщиной $20 \div 40$ мкм методом, обеспечивающим требуемую для стеклования скорость охлаждения $\sim 10^{6} \mathrm{~K} / \mathrm{c}$. В конце 1990 -х годов удалось создать металлические композиции, допускающие стеклование даже при скоростях закалки $1 \div 10^{-1} \mathrm{~K} / \mathrm{c}[65,66]$. При этом стало возможным получение МС толщиной 1 см и более. Такие стекла стали называть массивными.

Важнейшей особенностью массивных металлических стекол, в отличие от стандартных ленточных МС, является большая разница между температурой стеклования и температурой кристаллизации, что позволяет проводить термообработку выше $T_{g}$. Это не только существенно расширило диапазон экспериментов, но и открыло возможности, нереализуемые в случае ленточных МС. 
Ранее на примерах ленточных МС было принято считать, что неупругая деформация МС при $20^{\circ} \mathrm{C}$ ниже $T_{g}$ является необратимым процессом. Однако Хоник с соавторами $[5,67]$ показали, что при термостимулировании вблизи и выше $T_{g}$ полностью восстанавливается (исчезает) неупругая деформация массивных металлических стекол. Следовательно, она оказывается замороженной обратимой деформацией, как и у других стекол.

Далее перейдем к обсуждению природы пластической (замороженной обратимой) деформации стеклообразных систем.

\section{6. Различные подходы к природе пластической деформации стеклооб- разных твердых тел \\ Для объяснения эффекта пластичности стекол предложены различные под-} ходы [3, 4, 11, 18, 19-27, 34]. По мнению многих исследователей он связан с зарождением под напряжением специфических мелкомасштабных дефектов элементарных сдвигов, получивших названия: «дислокации Сомилианы», «незавершенные сдвиги», «пластические сдвиговые трансформации». В последнее время они получили общее название «сдвиговых трансформаций» [20, 23]. Они образуются в малых объемах стекла и создают локальную пластическую деформацию. Их накопление ведет к появлению остаточных макроскопических пластических деформаций.

Олейник с соавторами $[16,68,69]$ провели систематические исследования термодинамики неупругой деформации стеклообразных органических полимеров. Измерения проводили при комнатной температуре в режиме одноосного сжатия. Оказалось, что запасание энергии стеклами начинается сразу же за гуковской упругостью. На ранних стадиях неупругой деформации $100 \%$ работы внешних сил переходит во внутреннюю энергию образца.

Для сравнения в сходных условиях проведены такие же измерения для монокристалла меди. Для него наблюдается совершенно другая ситуация: сразу за гуковской упругостью практически вся внешняя работа рассеивается в виде деформационной теплоты. Такая разница в термодинамическом поведении стекол и меди свидетельствует о принципиальном различии в механизмах деформации кристаллов и стекол.

Сравнение начальных (ранних) и последующих после зуба текучести стадий деформации стеклообразных полимеров показывает, что с самого начала появления неупругого отклика материала главным контролирующим общую кинетику деформации механизмом процесса является зарождение сдвиговых трансформаций структуры. Именно зарождение и накопление таких трансформаций ответственно за рост внутренней энергии в ходе деформирования. Негуковскую, но обратимую при термостимулировании составляющую деформации называют запаздывающе- упругой, нелинейно-упругой или последействием. Мы пользуемся термином «замороженная обратимая деформация».

В кристаллах основными элементарными носителями пластической деформации являются специфические дефекты - так называемые краевые дислокации, которые являются линейными дефектами кристаллической решетки. Деформационное тепло в кристаллах появляется при скольжении этих дислокаций 
вдоль линии скольжения из-за трения о решетку. В стеклах нет таких дефектов - дислокаций и нет линий скольжения из-за отсутствия дальнего порядка.

Опыты показывают [68], что вся энергия, запасенная в деформированном стекле, выделяется при нагревании ниже $T_{g}$ в стеклообразном состоянии.

Стеклообразное твердое тело, накапливая такие структурные перестройки как локальные сдвиговые трансформации, при деформации переходит в состояние с повышенной энергией. Естественно, что при разгрузке это состояние стремится исчезнуть, а структура возникших сдвиговых трансформаций - отрелаксировать к исходному, недеформированному состоянию, скорость такой релаксации определяется барьером возврата. Ясно, что сдвиговые трансформации, возникшие при малых напряжениях $\sigma$, рождаются сравнительно легко и локальные перестройки структуры тела при образовании таких сдвиговых трансформаций незначительны. Согласно Олейнику с соавторами $[68,69]$, именно это свойство сдвиговой трансформации делает барьер возврата локальной деформиро-

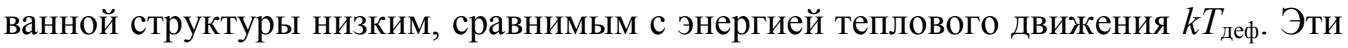
«слабые» сдвиговые трансформации ответственны за процесс запаздывающей упругости - за процесс термостимулированной релаксации пластической деформации стекол. Этот факт согласуется с низкой энергией активации пластической деформации силикатных стекол.

Таким образом, Олейник с соавторами $[16,23,24]$ последовательно развивают представление о том, что пластическая деформация и ее термостимулированная релаксация протекают не в исходной, а в иной структуре, возникающей в процессе деформации. Локальные сдвиговые трансформации возникают под действием внешнего напряжения и исчезают при нагревании ниже и вблизи $T_{g}$.

Луковкин и Аржаков [25] считают, что пластичность стекол является следствием исходной структурной неоднородности аморфных систем. Предполагается, что пластическая деформация связана с последовательным размягчением структурных микрообластей, характеризующихся локальными температурами размягчения. Тем самым они допускают тесную взаимосвязь между замороженной обратимой деформацией стекол и их размягчением при нагревании - процессом, обратным стеклованию.

Интересно отметить, что пластическая деформация стекол вполне удовлетворительно описывается формально с помощью математического аппарата дислокационной теории пластичности кристаллов $[19,21]$. Однако до сих пор не найдены в стеклообразных телах дефекты, подобные краевой дислокации, которая, как отмечалось выше, является дефектом кристаллической решетки. А в стеклах нет такой решетки. Тем не менее, дислокационная аналогия несомненно заслуживает внимания.

В Бурятском государственном университете развито представление о том, что элементарным актом пластической деформации стекол служит делокализация атома - предельное его смещение из локального равновесного положения $[10,34]$. Делокализация атома обусловлена флуктуацией ближнего порядка аморфного вещества (перегруппировкой соседних частиц) и отражает локальное конфигурирационное изменение структуры. Концентрация делокализованных атомов довольно сильно (экспоненциально) зависит от температуры и механического напряжения $[6,7,15]$. В направлении действия механического напряжения 
концентрация делокализованных атомов возрастает. Важным параметром модели делокализованных атомов является флуктуационный объем аморфного вещества, обусловленный делокализацией атомов. Приложение этой модели к пластичности стекол подробно рассмотрено в разделе 7. По-видимому, делокализацию атома можно рассматривать как некоторый аналог локальной сдвиговой трансформации. В частности, из этой модели следует, что пластическая деформация стеклообразных материалов обратно пропорциональна параметру Грюнайзена мере ангармонизма колебаний решетки и нелинейности силы межатомного взаимодействия. К такому же заключению приводит фононная концепция пластичности стекол (разделы 7.6 и 8).

За рубежом появилась серия публикаций, посвященных проблеме пластичности стекол (см., например, работы [18, 20, 70, 71]). Представляет интерес работа Benzine с соавторами [18], где локальную пластичность стеклообразных систем сравнивают с другим универсальным для стекол явлением, а именно наличием в спектрах комбинационного рассеяния света (КР) низкочастотного, так называемого бозонного пика, который связывают с радиусом корреляции неупорядоченной структуры жидкостей и стекол $R_{c}=v_{\mathrm{s}} / \omega_{\max }$, где $v_{\mathrm{s}}-$ скорость звука, $\omega_{\max }$ - частота, соответствующая данному пику ${ }^{72}$. Прослеживается определенная связь между параметрами модели делокализованных атомов и характеристиками низкочастотного бозонного пика в спектре КР, в частности, между энергией делокализации атома $\Delta \varepsilon_{\mathrm{e}}$ и частотой максимума $\omega_{\max }: \Delta \varepsilon_{e}=C h \omega_{\max }$, где $C$ - коэффициент пропорциональности, $\mathrm{h}$ - постоянная Планка. Так, линейная корреляция между $\omega_{\max }$ и $T_{g}$ [72] находится в согласии с корреляцией между $\Delta \varepsilon_{e}$ и $T_{g}$ (раздел 7). Бозонный пик у силикатных стекол характеризуется низкой энергией активации 20 кДж/моль, близкой к $\Delta \varepsilon_{e}$. Относительное число делокализованных атомов определяется по формуле, которая по внешнему виду совпадает с известным соотношением Бозе-Эйнштейна при $\Delta \varepsilon_{e}=\mathrm{h} v$ (например, формула (13.8) в работе [15]).

На основе теории свободного объема, развитой для процесса стеклования, удалось установить связь между пределом текучести и релаксацией объема аморфных полимеров в процессе отжига ниже температуры стеклования. Показано, что один и тот же термически активированный процесс контролирует как пластическую деформацию, так и структурную релаксацию. Оказывается, что молекулярные параметры, в частности, энергия образования дырки, входящие в теорию стеклования, успешно используются при описании поведения предела текучести в зависимости от скорости охлаждения, времени отжига, температуры и скорости деформации [70].

В целом необходимо отметить, что природа эффекта пластичности стекол остается до конца нерешенной проблемой.

7. Применение модели делокализованных атомов к пластической деформации стеклообразных твердых тел

В молекулярно-кинетических процессах, протекающих в жидкостях и аморфных веществах, важную роль играет элементарный механизм, обусловленный делокализацией атома - его предельным смещением из локального равновесного положения [6-10]. Как отмечено выше, делокализация атома обусловле- 
Сандитов Д. С. Эффект пластичности стекол в модели делокализованных атомов

на флуктуацией ближнего порядка и, по существу, отражает локальное конфигурационное структурное изменение.

\section{1. Стеклование жидкости и делокализация атома}

В силикатных стеклах делокализация атома представляет собой предельное смещение мостикового атома кислорода в мостике Si-O-Si, связанное с локальной низкоактивационной деформацией кремнекислородной сетки [7]. Полагаем, что делокализация атома служит необходимым условием реализации элементарного акта процесса вязкого течения неорганических стекол, например, переключения валентной связи по Мюллеру Р. Л. [11], а также образования флуктуационной дырки по Френкелю Я. И. [73] в случае вязкого течения простых жидкостей.

Без делокализации атома («пускового механизма» текучести) невозможно вязкое течение. Поэтому замораживание процесса делокализации активного атома в области стеклования приводит к прекращению вязкого течения и к переходу расплава в стеклообразное состояние. Этот момент наступает тогда, когда энергия тепловых колебаний решетки, отнесенная к атому, становится равной или меньше энергии делокализации атома: $(i / 2) \mathrm{kT} \leq \Delta \varepsilon_{\mathrm{e}}$, что приводит к следующему условию перехода жидкость - стекло

$$
\frac{i}{2} k T_{g} \cong \Delta \varepsilon_{e}
$$

где $i$ - число степеней свободы кинетической единицы, ответственной за стеклование, $T_{\mathrm{g}}$ - температура перехода.

Энергия делокализации атома

$$
\Delta \varepsilon_{e}=p_{i} \Delta \mathrm{v}_{e}
$$

тесно связана с предельной упругой деформацией связи между атомами, и она равна работе предельного смещения атома, совершаемой против внутреннего давления $p_{i}$, обусловленного силами межатомного (межмолекулярного) притяжения. Здесь $\Delta \mathrm{v}_{e}$ - элементарный флуктуационный объем, необходимый для смещения атома (объем делокализации атома) $[6,7]: \Delta \mathrm{v}_{e}=\pi d^{2} \Delta r_{m}, \pi d^{2}-$ площадь эффективного сечения атома, $\Delta r_{m}$ - предельное смещение атома из локального равновесного положения.

Как и следовало ожидать, в соответствии с критерием (7.1) энергия $\Delta \mathrm{v}_{e}$, определенная независимым способом ( $R$ - газовая постоянная),

$$
\Delta \mathrm{v}_{e}=\mathrm{RD} \text {, }
$$

для силикатных, германатных и боратных стекол [9] линейно зависит от температуры стеклования $T_{g}$ (рис. 7.1, 7.2). Здесь $D$ - эмпирический параметр уравнения Енкеля $[74,75]$

$$
\eta=A \exp \left[\frac{B}{T}+\frac{C}{T} \exp \left(\frac{D}{T}\right)\right],
$$

успешно описывающего температурную зависимость вязкости $\eta(T)$ стеклообразующих жидкостей в широком интервале температур. У сульфатно-фосфатных стекол $\mathrm{NaPO}_{3}-\mathrm{MeSO}_{4}(\mathrm{Me}=\mathrm{Li}, \mathrm{Na}, \mathrm{K})$ между энергией делокализации атома $\Delta \varepsilon_{e}$ и температурой стеклования $T_{g}$ наблюдается также линейная корреляция (рис. 7.3). Величина $\Delta \varepsilon_{e}$ рассчитана по формуле (табл. 7.1) 


$$
\Delta \varepsilon_{e}=\mathrm{Rc},
$$

где $c$ - эмпирическая постоянная в уравнении Брэдбури - Шишкина $[76,77]$

$$
\eta=\eta_{o} \exp \left[a \exp \left(\frac{c}{T}\right)\right],
$$

которое описывает зависимость $\eta(T)$ в области стеклования.

При выводах уравнений вязкости (7.4) и (7.6) в рамках модели делокализованных атомов и активационной теории вязкости величины $R D$ и $R c$ приобретают смысл энергии делокализации атома $\Delta \varepsilon_{e}[7,15,78,79]$.

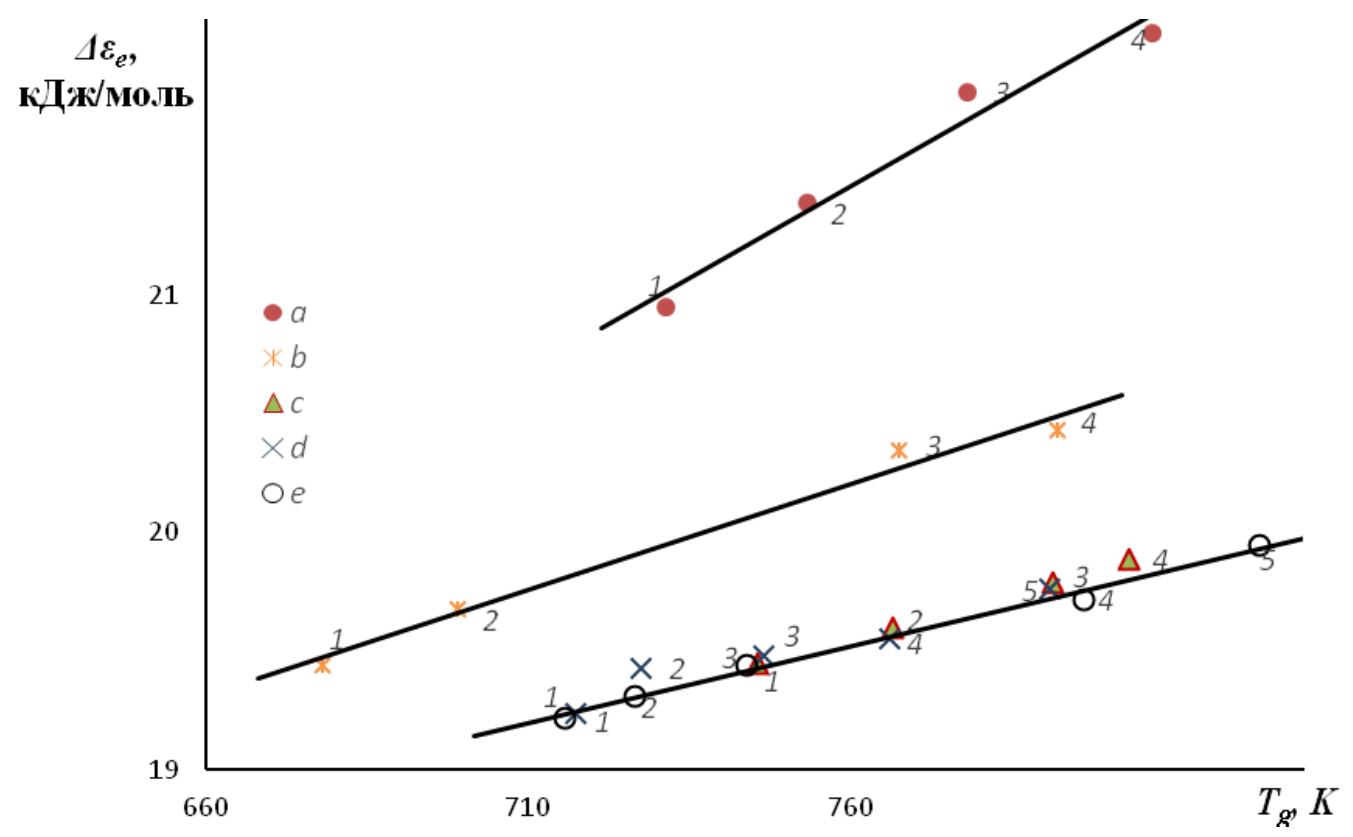

Pис. 7.1. Линейная корреляция между энергией делокализации атома $\Delta \varepsilon_{e}=R D$ и температурой стеклования $T_{g}$ для силикатных и германатных стекол.

$D$ - параметр уравнения Енкеля (7.4). $a-\mathrm{GeO}_{2}-\mathrm{Na}_{2} \mathrm{O}$ (содержание $\mathrm{Na} 2 \mathrm{O}$, мол. \%: $1-30,2-25,3-20,4-15) ; b-\mathrm{SiO}_{2}-\mathrm{PbO}$ (PbO, мол. \%: $1-50,2-45,3-30$, $4-24,6) ; c-\mathrm{SiO}_{2}-\mathrm{K}_{2} \mathrm{O}\left(\mathrm{K}_{2} \mathrm{O}\right.$, мол. \%: $\left.1-25,2-20,3-15,4-13\right) ; d-\mathrm{SiO}_{2}-\mathrm{Na}_{2} \mathrm{O}$ ( $\mathrm{Na}_{2} \mathrm{O}$, мол. \%: $\left.1-33,2-30,3-25,4-20,5-15\right) ; e-\mathrm{SiO}_{2}-\mathrm{Li}_{2} \mathrm{O}$ (Li2 $\mathrm{O}$, мол. \%: $1-33,3,2-30,3-25,4-14,5-10$ ). 


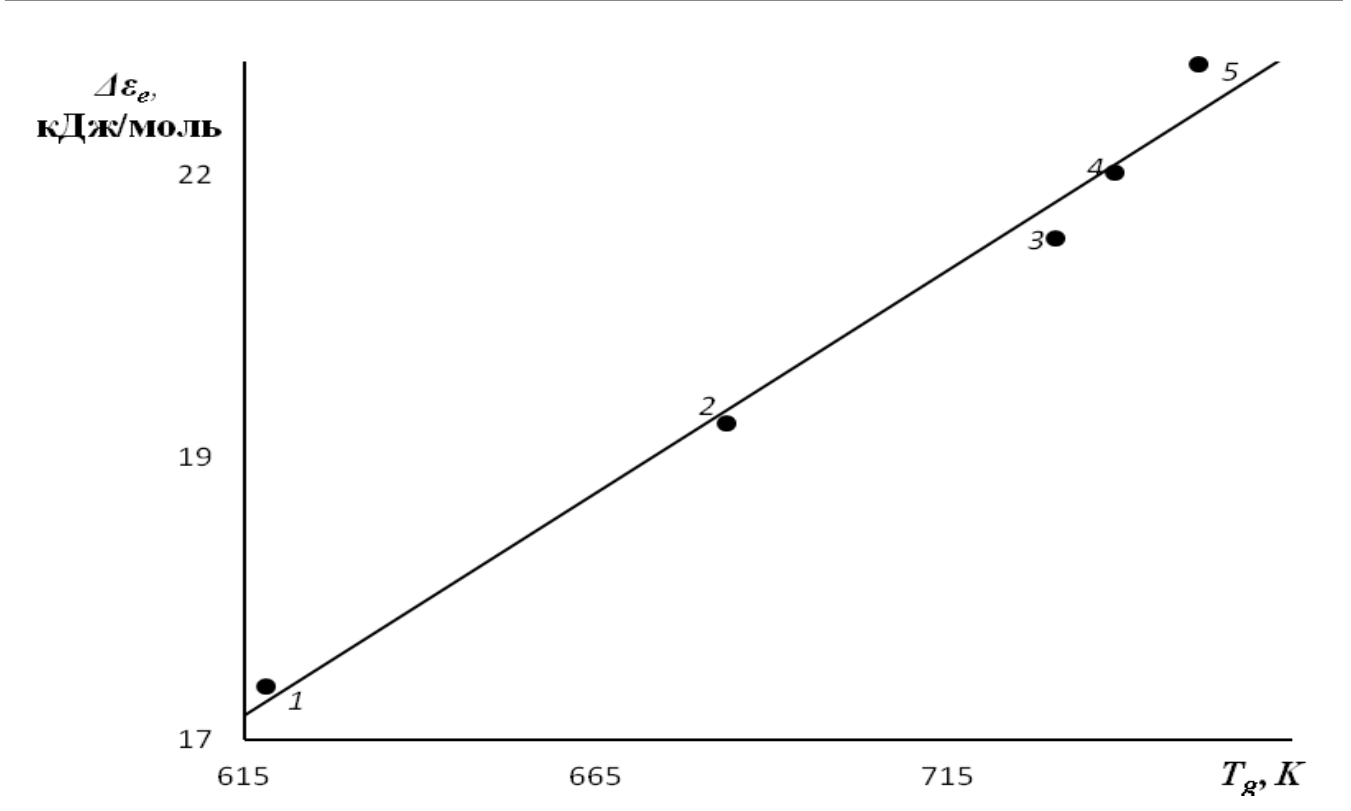

Рис. 7.2. Зависимость энергии делокализации атома $\Delta \varepsilon_{e}=R D$ от температуры стеклования $T_{g}$ для натриевоборатных стекол $\mathrm{Na}_{2} \mathrm{O}-\mathrm{B}_{2} \mathrm{O}_{3}$. D - параметр уравнения Енкеля (7.4).

Содержание $\mathrm{Na}_{2} \mathrm{O}$, мол.\%: 1 - 10, 2 - 15, 3 - 20, 4-25, 5 - 30.

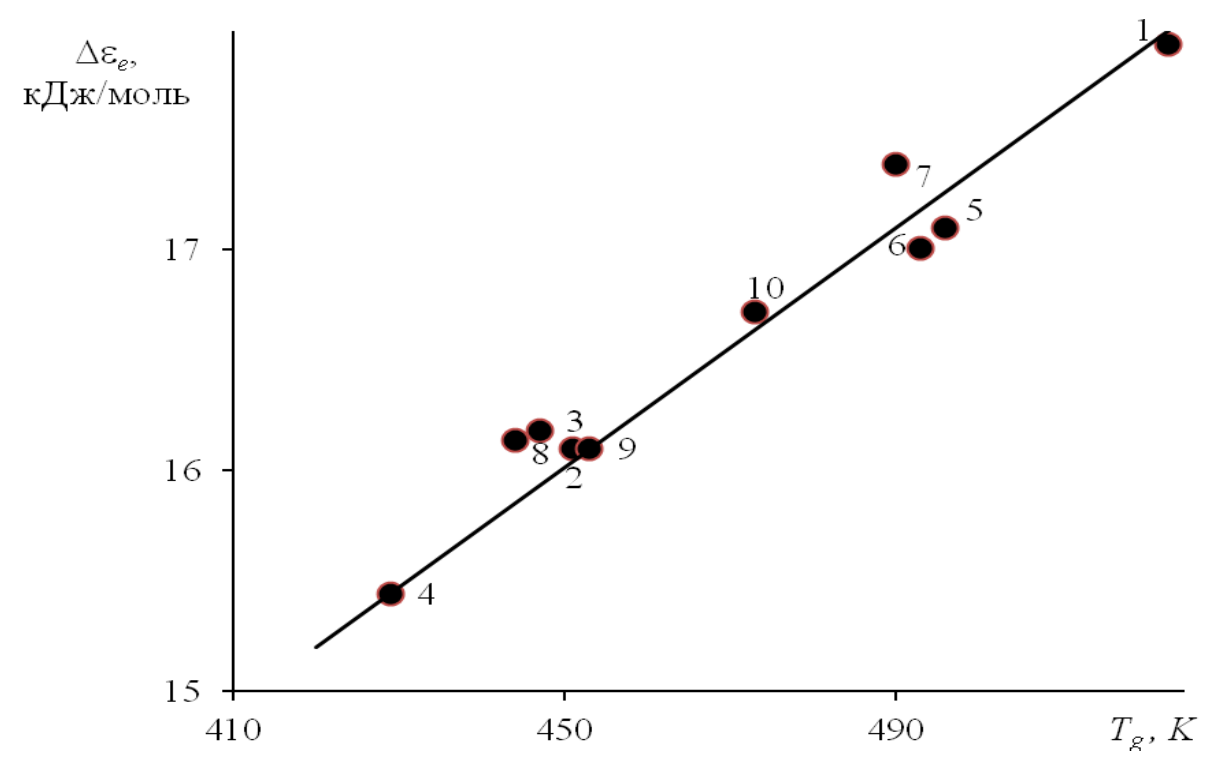

Рис. 7.3. Корреляция между энергией делокализации атома $\Delta \varepsilon_{e}$

и температурой стеклования $T_{g}$ сульфатно-фосфатных стекол. $1-\mathrm{NaPO}_{3}, \mathrm{NaPO}_{3}-\mathrm{Li}_{2} \mathrm{SO}_{4}$, содержание $\mathrm{Li}_{2} \mathrm{SO}_{4}$, мол.\%: 2 - 10, 3 - 20, 4 - 30; $\mathrm{NaPO}_{3}-\mathrm{Li}_{2} \mathrm{SO}_{4}$, содержание $\mathrm{Na}_{2} \mathrm{SO}_{4}$, мол.\%: $5-10,6-20,7-30 ; \mathrm{NaPO}_{3}-\mathrm{K}_{2} \mathrm{SO}_{4}$, содержание $\mathrm{K}_{2} \mathrm{SO}_{4}$, мол.\%: $8-10,9-20,10-30$. 
Таблица 7.1

Свойства сульфатно-фосфатных стекол $\mathrm{NaPO}_{3}-\mathrm{MeSO}_{4}(\mathrm{Me}=\mathrm{Li}, \mathrm{Na}, \mathrm{K})$ и параметры модели делокализованных атомов (использованы данные [101]). $a$ и $c$ - параметры уравнения (7.6).

\begin{tabular}{|c|c|c|c|c|c|c|c|c|c|c|}
\hline \multirow[t]{2}{*}{ № } & \multirow[t]{2}{*}{ Стекло } & \multirow[t]{2}{*}{$\begin{array}{l}T_{g}, \\
K\end{array}$} & \multirow{2}{*}{$\begin{array}{c}E, \\
\text { кгс } \\
\mathrm{MM}^{2}\end{array}$} & \multirow[t]{2}{*}{$\mu$} & \multirow[t]{2}{*}{$a$} & \multirow[t]{2}{*}{$\begin{array}{l}c, \\
K\end{array}$} & \multirow[t]{2}{*}{$f_{g}$} & \multicolumn{2}{|c|}{$\begin{array}{c}\Delta \varepsilon_{\mathrm{e}} \\
\text { кДж/моль }\end{array}$} & \multirow{2}{*}{$\begin{array}{l}\Delta \mathrm{v}_{e}, \\
\stackrel{\circ}{\mathrm{A}}^{3}\end{array}$} \\
\hline & & & & & & & & $\begin{array}{l}(7.5) \\
\end{array}$ & (7.9) & \\
\hline 1 & $\mathrm{NaPO}_{3}$ & 523 & 3610 & 0.294 & 0.99 & 2160 & 0.016 & 17.9 & 17.9 & 16 \\
\hline 2 & $\begin{array}{l}0.9 \mathrm{NaPO}_{3}-0.1 \\
\mathrm{Li}_{2} \mathrm{SO}_{4}\end{array}$ & 451 & 4140 & 0.300 & 0.97 & 1940 & 0.014 & 16.0 & 16.1 & 13 \\
\hline 3 & $\begin{array}{l}0.8 \mathrm{NaPO}_{3}-0.2 \\
\mathrm{Li}_{2} \mathrm{SO}_{4}\end{array}$ & 447 & 4210 & 0.303 & 0.95 & 1950 & 0.013 & 16.1 & 16.2 & 14 \\
\hline 4 & $\begin{array}{l}0.7 \mathrm{NaPO}_{3}-0.3 \\
\mathrm{Li}_{2} \mathrm{SO}_{4}\end{array}$ & 429 & 4230 & 0.034 & 0.95 & 1860 & 0.014 & 15.2 & 15.4 & 11 \\
\hline 5 & $\begin{array}{l}0.9 \mathrm{NaPO}_{3}-0.1 \\
\mathrm{Na}_{2} \mathrm{SO}_{4}\end{array}$ & 496 & 3730 & 0.299 & 0.97 & 2060 & 0.016 & 17.0 & 17.1 & 14 \\
\hline 6 & $\begin{array}{l}0.8 \mathrm{NaPO}_{3}-0.2 \\
\mathrm{Na}_{2} \mathrm{SO}_{4}\end{array}$ & 493 & 3550 & 0.292 & 0.96 & 2050 & 0.016 & 16.9 & 17.0 & 15 \\
\hline 7 & $\begin{array}{l}0.7 \mathrm{NaPO}_{3}-0.3 \\
\mathrm{Na}_{2} \mathrm{SO}_{4}\end{array}$ & 490 & 3540 & 0.288 & 0.95 & 2095 & 0.015 & 17.1 & 17.4 & 16 \\
\hline 8 & $\begin{array}{l}0.9 \mathrm{NaPO}_{3}-0.1 \\
\mathrm{~K}_{2} \mathrm{SO}_{4}\end{array}$ & 444 & 3380 & 0.316 & 0.95 & 1945 & 0.013 & 16.0 & 16.1 & 16 \\
\hline 9 & $\begin{array}{l}0.8 \mathrm{NaPO}_{3}-0.2 \\
\mathrm{~K}_{2} \mathrm{SO}_{4}\end{array}$ & 453 & 3350 & 0.316 & 0.96 & 1940 & 0.014 & 16.0 & 16.1 & 15 \\
\hline 10 & $\begin{array}{l}0.7 \mathrm{NaPO}_{3}-0.3 \\
\mathrm{~K}_{2} \mathrm{SO}_{4}\end{array}$ & 473 & 3340 & 0.313 & 0.99 & 2015 & 0.014 & 16.8 & 16.7 & 16 \\
\hline
\end{tabular}

В результате делокализации (тепловых смещений) атомов в жидкостях и аморфных твердых телах возникает флуктуационный объем

$$
\Delta \mathrm{V}_{\mathrm{s}}=\mathrm{N}_{\mathrm{s}} \Delta \mathrm{v}_{\mathrm{s}}
$$

где $N_{e}$ - число делокализованных атомов.

У неорганических стекол, металлических аморфных сплавов, аморфных органических полимеров и низкомолекулярных органических стекол доля флуктуационного объема $f_{g}$, замороженная при температуре стеклования $T_{g}$, слабо зависит от природы стекол (табл. 7.2)

$$
f_{g}=\left(\frac{\Delta V_{e}}{V}\right)_{T=T_{g}} \approx 0.025 \div 0.030
$$

У стекол одного типа она практически постоянна. Например, у натриевосиликатных стекол: $f_{g} \approx c o n s t=0.028$ (табл. 7.2). Величина $f_{g}$ определяется по данным о вязкости в области стеклования $[7,8]$. У сульфатно-фосфатных стекол значения $f_{g}$ меняются также в небольших пределах $\left(f_{g} \approx c o n s t\right)$, однако заметно ниже, чем у силикатных стекол (табл. 7.1). Доля флуктуационного объема $f_{g}$ входит в формулы модели делокализованных атомов (например, (7.9)). 
Параметры уравнения Вильямса-Ландела-Ферри (ВЛФ) $C_{1}, C_{2}$ и доля флуктуационного объема $f_{g}$, замороженная при температуре стеклования $T_{g}[6,7]$

\begin{tabular}{|c|c|c|c|c|c|c|}
\hline $\begin{array}{c}\text { Аморфное } \\
\text { вещество }\end{array}$ & $\begin{array}{c}T_{g} \\
K\end{array}$ & $C_{1}$ & $\begin{array}{c}C_{2} \\
K\end{array}$ & $f_{g}$ & $\ln \left(1 / f_{g}\right)$ & $\begin{array}{c}\Delta \varepsilon_{e}, \\
\text { кДж/моль }\end{array}$ \\
\hline \multicolumn{7}{|c|}{ Натриевосиликатные стекла $\mathrm{Na}_{2} \mathrm{O}-\mathrm{SiO}_{2}$} \\
\hline \multicolumn{7}{|l|}{$\mathrm{Na}_{2} \mathrm{O}$, мол. \% } \\
\hline 15 & 782 & 36 & 430 & 0.028 & 3.6 & 23 \\
\hline 20 & 759 & 36 & 390 & 0.028 & 3.6 & 23 \\
\hline 25 & 739 & 35 & 355 & 0.028 & 3.6 & 22 \\
\hline 30 & 721 & 35 & 322 & 0.028 & 3.6 & 22 \\
\hline 33 & 712 & 35 & 304 & 0.028 & 3.6 & 21 \\
\hline 35 & 705 & 35 & 291 & 0.028 & 3.6 & 21 \\
\hline \multicolumn{7}{|c|}{ Металлические стекла (аморфные сплавы) } \\
\hline $\mathrm{Pd}_{40} \mathrm{Ni}_{40} \mathrm{P}_{20}$ & 602 & 39 & 93 & 0.026 & 3.6 & 18 \\
\hline $\mathrm{Pt}_{60} \mathrm{Ni}_{15} \mathrm{P}_{25}$ & 500 & 37 & 95 & 0.027 & 3.6 & 15 \\
\hline $\mathrm{Pd}_{77.5} \mathrm{Cu}_{6} \mathrm{Si}_{16.5}$ & 653 & 38 & 100 & 0.026 & 3.6 & 19 \\
\hline $\mathrm{Fe}_{80} \mathrm{P}_{13} \mathrm{C}_{7}$ & 736 & 38 & 120 & 0.026 & 3.6 & 22 \\
\hline \multicolumn{7}{|c|}{ Аморфные органические полимеры и селен } \\
\hline Поливинилацетат & 305 & 36 & 47 & 0.028 & 3.6 & 9 \\
\hline Натуральный каучук & 300 & 38 & 54 & 0.026 & 3.6 & 9 \\
\hline Метакрилат этиловый & 335 & 40 & 65 & 0.025 & 3.6 & 10 \\
\hline Селен & 303 & 32 & 58 & 0.031 & 3.5 & 9 \\
\hline \multicolumn{7}{|c|}{ Низкомолекулярные органические стекла } \\
\hline Пропанол & 98 & 41 & 25 & 0.024 & 3.7 & 3 \\
\hline Протиленгликоль & 160 & 44 & 40 & 0.023 & 3.8 & 5 \\
\hline Глицерин & 185 & 42 & 53 & 0.024 & 3.7 & 6 \\
\hline
\end{tabular}

Примечание: уравнение ВЛФ: $\ln a_{\mathrm{T}}=-C_{1}\left(T-T_{g}\right) /\left(T-T_{g}+C_{2}\right), a_{T}=\eta(T) / \eta\left(T_{g}\right)$, $f_{g}=1 / C_{1}, \Delta \varepsilon_{e}=R T_{g} \ln \left(1 / f_{g}\right)$.

Предполагаем, что вязкое течение расплавов неорганических стекол выше $T_{g}$ наряду с другими причинами реализуется главным образом за счет возбужденных делокализованных мостиковых атомов с энергией возбуждения $\Delta \mathrm{v}_{e}$. У щелочносиликатных стекол эта энергия составляет около (табл. 7.2) [6, 7]

$$
\Delta \varepsilon_{\mathrm{e}} \approx \mathrm{RT}_{\mathrm{g}} \ln \left(1 / \mathrm{f}_{\mathrm{g}}\right) \approx 20 \text { кДж/моль }
$$

Расчет энергии делокализации атома по формуле (7.3) из данных об эмпирической постоянной $D=2500 \mathrm{~K}$ (табл. 7.3) [75] для щелочносиликатного стекла

$$
\Delta \varepsilon_{\mathrm{e}}=\mathrm{RD}=2120 \text { кДж/моль }
$$

находится в согласии с результатами расчета по уравнению модели делокализованных атомов (7.9). 
Таблица 7.3.

Эмпирические постоянные уравнения Енкеля (7.4) и вычисленные из них характеристики вязкого течения и стеклования аморфных веществ $\left(\Delta F_{\infty}=R B\right.$ и $\left.\Delta \varepsilon_{e}=R D\right)$

\begin{tabular}{|c|c|c|c|c|c|}
\hline \multirow{2}{*}{ Вещество } & $B$ & $D$ & $\Delta F_{\infty}$ & $\Delta \varepsilon_{\mathrm{e}}$ & \multirow{2}{*}{ Литература } \\
\cline { 2 - 5 } & \multicolumn{2}{|c|}{$\mathrm{K}$} & \multicolumn{2}{|c|}{ кДж/моль } & \\
Силикатное стекло & & & & & \\
№15 & 13226 & 2500 & 110 & 21 & {$[75]$} \\
№18 & 13348 & 2500 & 111 & 21 & {$[75]$} \\
Na2O 3SiO $2_{2}$ & - & 1840 & - & 15 & {$[74]$} \\
Минеральное масло: & & & & & \\
XII & 1195 & 800 & 10 & 7 & {$[75]$} \\
XIII & 928 & 700 & 8 & 6 & {$[75]$} \\
XIV & 741 & 600 & 6 & 5 & {$[75]$} \\
XV & 686 & 600 & 6 & 5 & {$[75]$} \\
XVI & 615 & 600 & 5 & 5 & {$[75]$} \\
Глицерин & - & 920 & - & 8 & {$[74]$} \\
Полиизобутилен & - & 460 & - & 4 & {$[74]$} \\
\hline
\end{tabular}

Примечание: $\Delta F_{\infty}$ - высокотемпературный предел свободной энергии активации вязкого течения стеклообразующих жидкостей.

Обращает внимание то обстоятельство, что энергия делокализации атома $\Delta \varepsilon_{e}$ по порядку величины сравнима со средней энергией теплового колебательного движения решетки в области стеклования. Последняя, например, по закону равнораспределения энергии по степеням свободы (согласно классическому выражению $\Delta \varepsilon_{D}=3 N_{A} k T=3 R T$ ) для силикатных стекол, у которых $T_{g} \approx 700-900 \mathrm{~K}$, составляет около:

$$
\Delta \varepsilon_{\mathrm{D}}=3 \mathrm{RT} \text { 列 } 17-22 \text { кДж/моль }
$$

Таким образом, в рамках развиваемых представлений стеклование жидкости связано с замораживанием процесса делокализации атома. Из рис. 7.1-7.3 следует, что у исследованных стекол энергия делокализации атома $\Delta \varepsilon_{e}$ линейно зависит от температуры стеклования.

7.2. Линейная корреляция между пределом текучести и температурой стеклования в модели делокализованных атомов

Представление о том, что элементарный акт пластической деформации стекол сводится к делокализации атома (кинетической единицы), находится в удовлетворительном согласии с экспериментальными данными: расчеты предела текучести и энергии активации этой деформации согласуются с экспериментом [34]. Энергия активации пластической деформации силикатных стекол $\Delta u \approx 20$ кДж/моль совпадает с энергией делокализации атома в них $\Delta u \approx \Delta \varepsilon_{\mathrm{e}}$.

Как и следовало ожидать, внутреннее давление неорганических стекол, против которого совершается работа делокализации атома, совпадает с микротвердостью этих систем $H_{V}-$ с пределом текучести $\sigma_{y} \cong H_{V}$, выше которого наблюдается пластическая деформация. Было показано, что для 79 силикатных, герма- 
натных и фосфатных стекол величина $p_{i}$ практически совпадает с их микротвердостью по Виккерсу $p_{i} \cong H_{V}$ [33]. С этих позиций внутреннее давление этих стекол может служить мерой предела текучести $p_{i} \approx \sigma_{y}$.

Предел текучести $\sigma_{y}$ имеет смысл напряжения, необходимого для критического смещения (делокализации) кинетической единицы. Как следует из приведенных выше соображений, по величине $\sigma_{y}$ совпадает с внутренним давлением

$$
p_{i}=\Delta \varepsilon_{e} / \Delta \mathrm{v}_{e},
$$

против которого совершается работа делокализации атома. Принимая во внимание равенство $\sigma_{\mathrm{y}}=p_{i}$ и подставив в это отношение энергию делокализации атома $\Delta \varepsilon_{e}(7.9)$, приходим к следующей связи между пределом текучести $\sigma_{\mathrm{y}}$ и температурой размягчения (температурой стеклования) $T_{g}$

$$
\sigma_{y}=\frac{k \ln \left(1 / f_{g}\right)}{\Delta \mathrm{v}_{e}} T_{g} .
$$

Как мы уже знаем, в качестве кинетических единиц, способных к делокализации, в неорганических стеклах выступают мостиковые «шарнирные» атомы типа мостикового атома кислорода в мостике $\mathrm{Si}-\mathrm{O}-\mathrm{Si}$. Поэтому объем делокализации атома $\Delta \mathrm{v}_{e}$ у стекол одного класса фактически одинаков: $\Delta \mathrm{v}_{e} \approx$ const $[6,7]$.

В соответствии с формулой (7.19) при $f_{g} \approx$ const и $\Delta \mathrm{v}_{e} \approx$ const для стекол одного типа должна наблюдаться линейная корреляция между величинами $\sigma_{y}$ и $T_{g}$, а также между $H_{V}$ и $T_{g}$. В самом деле, у аморфных полимеров между $\sigma_{y}$ и $T_{g}$ обнаруживается линейная корреляция (рис. 7.4) [34]. Как видно из рис. 7.5 и 7.6, микротвердость (предел текучести) ряда стекол также линейно зависит от температуры стеклования $T_{g}[11,80,81]$.

Таким образом, данный подход дает один из вариантов объяснения наличия линейной корреляции между пределом текучести и температурой размягчения стекол.

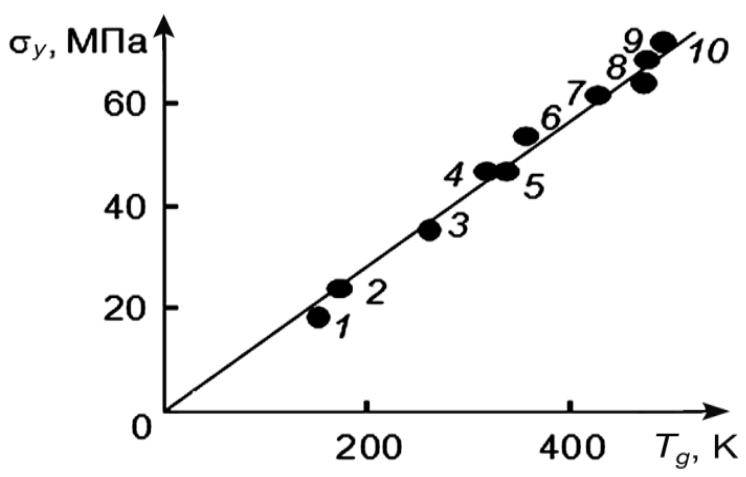

Рис. 7.4. Линейная корреляция между пределом текучести бу и температурой стеклования $T_{\mathrm{g}}$ аморфных полимеров. 1 - политетрафторэтилен, 2 - полиэтилен, 3 - полипропилен, 4 - полиамид, 5 - полиэтилентерефталат, 6 - поливинилхлорид, 7 - поликарбонат, 8 - полиарилатсульфон, 9 - полисульфон, 10 - полиарилат. 


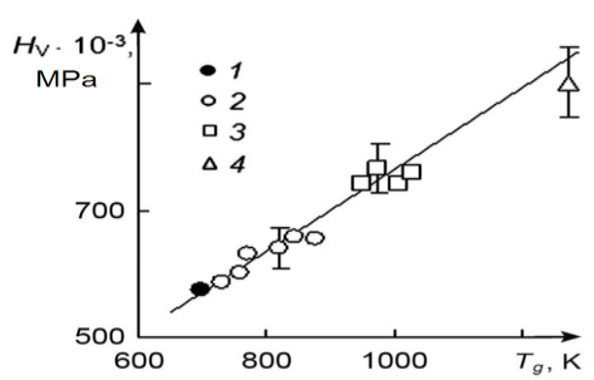

Рис. 7.5. Корреляция между микротвердостью $H_{V}$ и температурой стеклования силикатных стекол. 1 - свинцовосиликатное, 2 - щелочносиликатные,

3 - алюмосиликатные, 4 - кварцевое

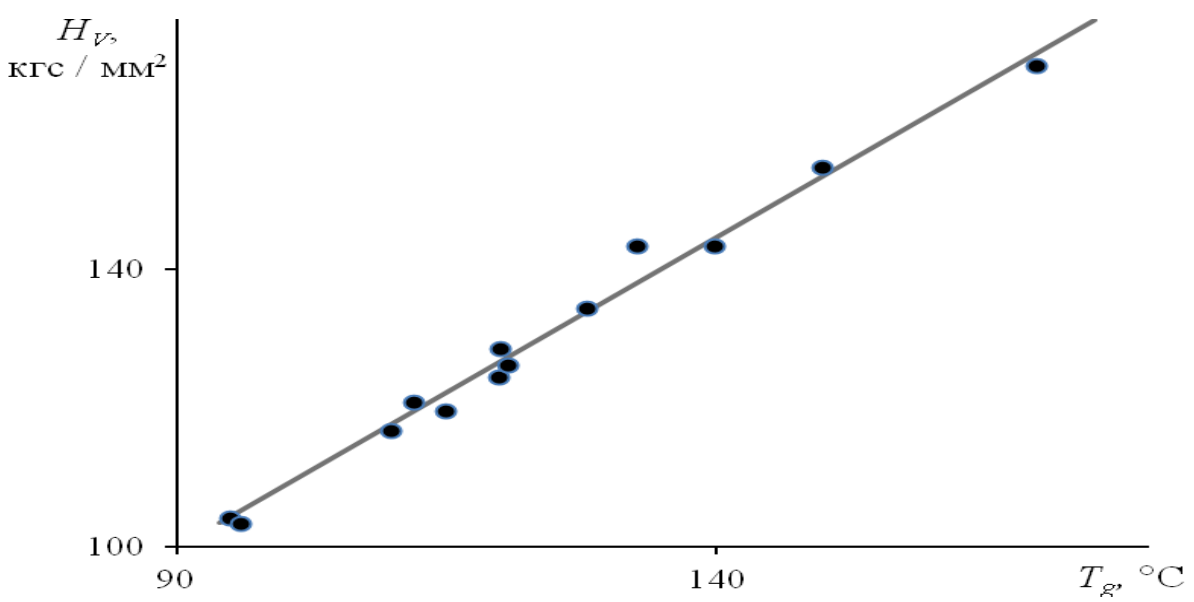

Рис. 7.6. Линейная корреляция между $H_{v}$ и $T_{g}$ для бескислородных халькогенидных стекол системы мышьяк-теллур-алюминий при различных содержаниях компонентов [80]

7.3. Зависимость скорости термостимулированной релаксации пластической деформации стекол от температуры и давления

Скорость восстановления пластически деформированных стеклообразных полимеров при нагревании $v_{r e l}$ как функция температуры и давления подчиняется следующей экспоненциальной зависимости [82]

$$
v_{r e l}=A \exp \left(-\frac{\Delta u+p \Delta \mathbf{v}_{y}}{k T}\right) .
$$

Для эпоксидного сеточного аморфного полимера получено значение активационного объема данного релаксационного процесса, равное [82]

$$
\Delta \mathrm{v}_{\mathrm{y}}=(55 \pm 8) \AA^{3}
$$

В модели делокализованных атомов скорость термостимулированного восстановления исходного недеформированного состояния стекла (7.20) определяется скоростью изменения числа делокализованных атомов в данном процессе

$$
v_{\text {rel }} \sim\left(\mathrm{dN}_{\mathrm{e}} / \mathrm{dt}\right),
$$

откуда зависимость (7.20) выводится из уравнения модели для относительного числа делокализованных атомов [6] 


$$
\frac{N_{e}}{N}=\exp \left(-\frac{\Delta \varepsilon_{e}+p \Delta \mathrm{v}_{e}}{k T}\right)
$$

Активационный объем $\Delta \mathrm{v}_{y}$ получает следующую трактовку: $\Delta \mathrm{v}_{y}=\Delta \mathrm{v}_{e}$. У сетчатых эпоксидных полимеров типа модифицированной эпоксидной смолы ЭД-16 значения объема делокализации атома $\Delta \mathrm{v}_{e}$, рассчитанные по формуле модели (7.15) [6]:

$$
\Delta \mathrm{v}_{e}=\frac{3(1-2 \mu) k T_{g}}{f_{g} E} \approx 45 \div 74 \stackrel{\circ}{ }^{3},
$$

имеют такой же порядок величины, что и приведенное выше значение активационного объема $\Delta \mathrm{v}_{y}$. Для указанных эпоксидных полимеров для расчета $\Delta \mathrm{v}_{e}$ приняты данные Филянова [83]: $T_{g}=358 \mathrm{~K}, \mu=0.33-0.37, E=(28-35) \cdot 10^{8}$ Па, $f_{g}=$ 0.025 .

Процессу «делокализации атома» в стеклообразных органических полимеpax соответствует предельное смещение небольшого участка основной цепи макромолекулы (предположительно группы атомов в соединительном звене) [6].

\section{8. Заключение}

В настоящее время нет общепризнанного объяснения пластической деформации стеклообразных систем. Наибольшее распространение получило представление о том, что пластичность неупорядоченных твердых тел (неорганических стекол, аморфных органических полимеров, металлических стекол и т. д.) возникает и развивается через зарождение и накопление специфических структурных мелкомасштабных дефектов (локальных микросдвигов), получивших общее название «сдвиговых трансформаций». Сдвиговые трансформации являются носителями пластической деформации стекол. Концентрация носителей возрастает до стадии стационарного пластического течения, после чего выходит на постоянный стационарный уровень.

Модель делокализованных атомов можно рассматривать как один из вариантов такого общего подхода к природе пластичности стекол. Из этой модели вытекает линейная корреляция между температурой стеклования жидкости $T_{\mathrm{g}}$ и пределом текучести - механическим напряжением $\sigma_{y}$, выше которого при $20^{\circ} \mathrm{C}$ наблюдается пластическая деформация стекол, что подтверждается экспериментальными данными. Это означает определенную взаимосвязь пластической деформации стекол и процесса стеклования. Можно предположить, что в окрестности температуры $T_{\mathrm{g}}$ происходят такие же обратимые конфигурационные изменения структуры, которые наблюдаются при пластической (замороженной обратимой) деформации стекол. Размягчение стекла при нагревании в области $T=T_{g}$ и пластическая деформация стекла под действием механического напряжения при $20^{\circ} \mathrm{C}$ определяются одним и тем же молекулярным механизмом, а именно делокализацией атома - его предельным смещением из локального равновесного положения, которое связано с локальным конфигурационным изменением структуры.

Развито представление о том, что делокализация атома - предельное смещение активного атома - служит необходимым условием реализации элементарного акта вязкого течения стекол и их расплавов. Поэтому замораживание 
процесса делокализации атома («пускового механизма текучести») в области стеклования приводит к прекращению вязкого течения и к переходу расплава в стеклообразное состояние. Этот момент наступает тогда, когда энергия тепловых колебаний решетки, отнесенная к атому, становится равной или меньше энтальпии делокализации атома. Отсюда следует определенный критерий стеклования, который находится в согласии с экспериментальными данными.

Наиболее удобным и доступным способом исследования пластичности хрупких неорганических стекол служит наноиндентирование - вдавливание заостренных инденторов (например, алмазной пирамидки Виккерса от микротвердомера). Напряженное состояние под индентором локализуется в малом микрообъеме, линейные размеры которого меньше среднего расстояния между дефектами. Поэтому на результаты измерений не влияют дефекты, особенно поверхностные микротрещины. После микровдавливания индентора на стекле остается пластичный микроотпечаток. Из анализа напряженного состояния при микровдавливании алмазной пирамидки Виккерса следует, что под индентором возникает локальная деформация сдвига и что микротвердость по Виккерсу $H_{V}=F / S$ ( $F$ - нагрузка на индентор, $S$ - площадь микроотпечатка), определяемая как среднее нормальное напряжение, по величине совпадает с максимальным касательным напряжением $\tau_{m}$ и служит характеристикой сопротивления материала сдвигу. Величина $H_{V}$ совпадает с пределом текучести $\sigma_{y}$, выше которого происходит пластическая деформация стекла.

Литература

1. Gehlhoff G., Thomas M. Measurement of mechanical properties of glasses // Z. Techn. Phys. 1926. V. 7. P. 105-120.

2. Bridgman P. W., Simon I. Effects of Very High Pressures on Glass // J. Appl. Phys. 1953. V. 24. P. 405-413.

3. Александров А. П. Морозостойкость высокомолекулярных соединений // В кн.: Труды 1-й и 2-й конференций по высокомолек. Соединениям. Москва: Изд-во АН СССР, 1945. C. 49.

4. Лазуркин Ю. С., Фогельсон Р. Л. О природе больших деформаций высокомолекулярных веществ в стеклообразном состоянии // ЖТФ. Т. 21, Вып. 3. С. 267-286.

5. Чах К., Ляхов С. А., Хоник В. А. Обратимая вязкоупругая деформация массивного металлического стекла // Деформация и разрушение материалов. 2006. № 8. С. 22-25.

6. Сандитов Д. С. Модель делокализованных атомов в физике стеклообразного состояния // ЖЭТФ. 2012. Т. 142, Вып. 1. С. 123-137.

7. Sanditov D. S., Ojovan M. I. On relaxation nature of glass transition in amorphous materials // Physica B. 2017. V. 532. P. 96-113.

8. Сандитов Д. С. О природе уравнения перехода жидкость-стекло // ЖЭТФ. 2016. Т. 150, Вып. 1(7). С. 144-154.

9. Сандитов Д. С., Дармаев М. В., Мантатов В. В. Новый подход к кинетическому критерию стеклования жидкости // Вестник Бурятского госуниверситета. Химия. Физика. 2020. № 1. С. 15-22.

10. Бадмаев С. С., Сангадиев С. Ш., Дармаев М. В., Сандитов Д. С. О модификации критерия стеклования сильновязких жидкостей // Вестник Бурятского госуниверситета. Химия. Физика. 2019. Вып. 4. С. 39-46.

11. Сандитов Д. С., Бартенев Г. М. Физические свойства неупорядоченных структур. Новосибирск: Наука, 1982. 258 с. 
Сандитов Д. С. Эффект пластичности стекол в модели делокализованных атомов

12. Ростиашвили В. Г., Иржак В. И., Розенберг Б. А. Стеклование полимеров. Ленинград: Наука, 1987. 201 с.

13. Мазурин О. В. Стеклование. Ленинград: Наука, 1986. - 158 с.

14. Тропин Т. В., Шмельцер Ю. В. П., Аксенов В. Л. Современные аспекты кинетической теории стеклования // Успехи физ. наук. 2016. V. 186. С. 47-76.

15. Сандитов Д. С., Ожован М. И. Релаксационные аспекты перехода жидкостьстекло // Успехи физ.наук. 2019. V. 189. С. 113-124.

16. Стрельников И. А., Олейник Э. Ф., Мазо М. А., Руднев С. Н., Саламатина О. Б. Механизм пластичности стеклообразных полимеров: картина по результатам компьютерного моделирования // Высокомолек. соед. Серия А. 2018. Т. 60, № 3. С. 3-57

17. Берлин А. А., Мазо М. А., Синельников Н. Н. Плавление и стеклование в бинарных системах дисков на плоскости // ДАН. 1998. Т. 359, № 175. С. 1209-1214.

18. Benzine O., Bruns S., Pan Zh., Dust K., Wondraczek L. Local Deformation of Glasses is Mediated by Rigidity Fluctuation on Nanometer Scale // Advanced Science. 2018. № 5. C. 1800916.

19. Синани А. Б., Степанов В. А. Прогнозирование деформационных свойств стеклообразных полимеров с помощью дислокационных аналогий // Механика композитных материалов. 1981. № 1. С. 109-115.

20. Argon A. S. The Physics of Deformation and Fracture of Polymers. New York: Cambridge Univ. Press, 2013. 532 p.

21. Малкин А. Я., Субботин А. В., Куличихин В. Г. Физико-химические и реологические механизмы устойчивости при растяжении полимерных струй // Успехи химии. 2020. T. 89, № 8. C. 811-823.

22. Sanditov D. S., Ojovan M. I., Darmaev M. V. Glass transition criterion and plastically deformation of glass // Physica B. 2020. V. 582. P. 411914.

23. Олейник Э. Ф., Руднев С. Н., Саламатина О. Б. Ступенчатый механизм зарождения пластической деформации в стеклообразных полимерах // ДАН. 2015. Т. 465, № 1. С. 4649.

24. Олейник Э. Ф., Саламатина О. Б., Руднев С. Н., Шеногин С. В. Новый подход к пластической деформации стеклообразных полимеров // Высокомолек. соед. Сер. А. 1993. Т. 35, № 11. С. 1819-1849.

25. Аржаков М. С., Луковкин Г. М., Аржаков С. А. О природе термостимулированной низкотемпературной релаксации деформации полимерных стекол // ДАН. 1999. Т. 369, № 5. C. $629-631$

26. Волынский А. Л., Бакеев Н. Ф. Структурные аспекты неупругой деформации стеклообразных полимеров // Высокомолек. соед. Сер. А. 2005. Т. 47, № 7. С. 1332-1367.

27. Волынский А. Л., Ефимов А. В., Гроховская Т. Е., Ярышева Л. М., Бакеев Н. Ф. О возможных причинах накопления внутренней энергии на ранних стадиях деформации стеклообразных полимеров // Высокомолек. соед. Сер. А. 2004. Т. 46, № 7. С. 1158-1168.

28. Cohen H. M., Ray R. Densification of glass at very high pressure // Phys. Chem. Glasses. 1965. V. 5. P. 149-161.

29. Шишкин Н. И. Стеклование жидкостей и полимеров под давлением. V. Образование уплотненных стекол // ФТТ. 1960. Т. 2, № 1. С. 350-357.

30. Christiansen E. B., Kistler S. S., Gogarty W. B. Irreversible compressibility of silica glass a means of determining the distribution of force in high-pressure cells // J. Amer. Ceram. Soc. 1962. V. 45, № 4. P. 172-177.

31. Mackenzie J. D. High-pressure effects on oxide glasses. II. Subsequent heat treatment // J. Amer. Ceram. Soc. 1963. V. 46. P. 470-476.

32. Mackenzie J. D. High-pressure Effects on Oxide Glasses: III, Densification in Nonrigid State // J. Amer. Ceram. Soc. 1964. V. 47, № 2. P. 76-80. 
33. Сандитов Д. С., Сангадиев С. Ш. Условие стеклования в теории флуктуационного свободного объема и критерий плавления Линдемана // Физика и химия стекла. 1998. Т. 24, № 4. С. 741-428.

34. Сандитов Д. С., Сангадиев С. Ш., Сандитов Б. Д. Пластичность и вязкость стеклообразных материалов // Деформация и разрушение материалов. 2013. № 3. С. 2-7.

35. Шрейнер Л. А. Твердость хрупких тел. Ленинград; Москва : ОГИЗ, 1949. 144 с.

36. Дертев Н. К. Некоторые механические свойства поверхностного слоя стекла: диссертация на соискание ученой степени доктора технических наук. Ленинград: ИХС АН CCCP. 1951. 138 c.

37. Balta F. J., Sanditov D. S., Privalko V. P. Review: the microhardness of non-crystalline materials // J. Mater. Sci. 2002. V. 37. P. 4507-4516.

38. Сандитов Б. Д., Сангадиев С. Ш., Мантатов В. В., Сандитов Д. С. Анализ напряженного состояния и пластической деформации аморфных полимеров и стекол при микровдавливании // Деформация и разрушение материалов. 2006. № 10. С. 41-46.

39. Бартенев Г. М., Сандитов Д. С. Природа деформации неорганических стекол при микровдавливании // ДАН СССР. 1967. Т. 176, № 1. С. 66-69.

40. Bartenev G. M., Sanditov D. S., Rasumovskaya I. V. Microhardness and structure inorganic Glasses // Eighth Internat. Congress on Glass. L. 1969. P. 226-227.

41. Bartenev G. M., Sanditov D. S., Rasumovskaya I. V. Untersuchung der deformierbarkeit anorganischer Glaser mittels der // Silikattechnik. 1969. Bd. 20, № 3. Р. 89-93.

42. Бартенев Г. М. Разумовская И. В., Сандитов Д. С. Природа деформации при микровдавливании и понятие микротвердости неорганических стекол. В кн.: Механические и тепловые свойства и строение неорганических стекол. Москва: Мин-во промышл-сти строит-х материалов СССР, 1972. 390 с.

43. Сандитов Д. С. Молекулярная подвижность и «микропластичность» неорганических стекол: диссертация на соискание ученой степени кандидата физико-математичеких наук. Москва: Московский гос. пед. ин-т им. В. И. Ленина, 1970. 345 с.

44. Гегузин Я. И., Шпунт А. А. Особенности термостимулированной релаксации микроотпечатков на стеклах и кристаллах // Кристаллография. 1959. Т. 4. С. 579-588.

45. Neely J. E., Mackenzie J. D. Hardness and low-temperature deformation of silica glass // J. Mater. Sci. 1968. V. 3. P. 603-609.

46. Сандитов Д. С., Бартенев Г.М. К вопросу о "пластичности" и прочности стекла // ДАН СССР. 1973. Т.209, № 6. С. 1322-1325.

47. Robredo J., Calvo M. L., Dusollier G. Quelques mesures sur la microdureté Vickers dans le verre // Verres et refractaires. 1970. V. 26. P. 49-62.

48. Разумовская И. В., Мухина Л. Л., Бартенев Г. М. К механизму деформации неорганического стекла при микровдавливании // ДАН СССР. 1973. Т. 213, № 4. С. 822-825.

49. Мухина Л. Л. Изучение молекулярного механизма деформации неорганических стекол методом микровдавливания: автореферат диссертации на соискание ученой степени кандидата физико-математических наук. Москва: Моск. гос. пед. ин-т имени В. И Ленина, 1975. 196 с.

50. Мухина Л. Л., Аскадский А. А., Бартенев Г. М., Разумовская И. В., Слонимский Г. А. О структуре и релаксационных свойствах неорганических стекол // Высокомолек. соед. Сер. А. 1973. Т. 15, № 3. С. 641-649.

51. Бартенев Г. М., Сандитов Д. С. Релаксационные процессы в стеклообразных системах. Новосибирск: Наука, 1986. 238 с.

52. Беркович Е. С., Крапошина Л. Б. Новый прибор ИМАШ глубинометр интерференционный для испытания на микротвердость по глубине отпечатка. Примеры его применения // Новое в области испытаний на микротвердость: сборник. Москва: Наука, 1974. C. $93-100$. 
Сандитов Д. С. Эффект пластичности стекол в модели делокализованных атомов

53. Nomoev A. V., Sanditov D. S., Syzrantsev V. V., Radnaev B. R., Schreiber M. // Physica B: Condensed Matter. 2019. V. 560. P. 23-27.

54. Evers M. Kennzeichnung der Microduktilita von Gläsern durch ihre innere Reibung // Glastech. Ber. 1964. Bd. 37. P. 345-348.

55. Komine N., Kawate Y., Obara A. // Bull. Electrotechn. Labor. (Japan). 1963. V. 27. P. 919-927.

56. Petzold A. Über temperaturabhängige Discontinuitäten der Mikrohärte von Glasern // Silikattechnik. 1975. V. 26. P. 278-289.

57. Александров А. П., Лазуркин Ю. С. Изучение полимеров. Высокоэластичная деформация полимеров // ЖТФ. 1939. Т. 9, № 14. С. 1250-1261.

58. Берлин А. А., Ротенбург Л., Басерст Р. Особенности деформации неупорядоченных полимеров и неполимерных твердых тел // Высокомолек. соед. Сер. А. 1992. Т. 34. С. 6-32.

59. Волынский А. Л., Ярышева А. Ю., Рухля Е. Г., Ефимов А. В., Ярышева Л. М., Бакеев Н. Ф. Деформационное размягчение стеклообразных и кристаллических полимеров // Успехи химии. 2013. Т. 82, № 10. С. 988-1006.

60. Аржаков М. С. Обобщенное описание механических и релаксационных свойств полимерного стекла: автореферат диссертации на соискание ученой степени доктора химических наук. Москва: МГУ, 2003. 48 с.

61. Arzhakov M. S. Temperature-induced relaxation in deformed polymer glasses // Intern. J. Polymeric Mater. 1998. V. 39, № 3-4. P. 289-311.

62. Олейник Э. Ф., Шеногин С. В., Парамзина Т. В., Руднев С. Н., Шантарович В. П. и др. Молекулярная мобильность в стеклообразных полимерах при пластической деформации // Высокомолек. соед. Сер. А. 1998. Т. 40, № 12. С. 1961-1962.

63. Новиков В. У., Козлов Г. В. Structure and properties of polymers in terms of fractal approach // Успехи химии. 2000. Т. 69, № 6. С. 572-599.

64. Salamatina O. B., Hohne G. W. H., Rudnev S. N., Olenik E. F. Work, heat and stored energy in compressive plastic deformation of glassy polymers // Termochim. Acta. 1994. V. 247. P. 1-18.

65. Johnson W. L. Bulk Glass-Forming Metallic Alloys: Science and Technology // Mater. Res. Bull. 1999. V. 24. P. 42-56.

66. Inoue A. Bulk Amorphous Alloys-Practical Characteristics and Applications-, Materials Science Foundations. 1999. V. 6 (Trans Tech Publications, Netherlands). 148 p.

67. Csach К., Ляхов С. А. Хоник В. А. Восстановление способности к вязкому течению объемного металлического стекла посредством термообработки // Письма в ЖТФ. 2007. Т. 33, № 12. C. 9-15.

68. Саламатина О. Б., Руднев С. Н., Bartczak Z., Galeski А., Олейник Э. Ф. Термодинамика неупругой деформации аморфной и кристаллической фаз линейного полиэтилена // Высокомолек. соед. Сер. А. 2011. Т. 53, № 9. С. 1524-1536.

69. Стрельников И. А., Мазо М. А., Балабаев Н. К., Олейник Э. Ф., Берлин А. А. Накопление энергии при пластической деформации стеклообразного полиметилена // ДАН. 2014. Т. 457, № 2. С. 193-196.

70. Ernsberger R.N. Role of densification in deformation of glasses under point loading // J. Amer. Ceram. Soc. 1968. V. 51, № 10. P. 545-552.

71. Möbus G., Ojovan M., Cook S., Tsai J., Yang G. Nano-scale quasi-melting of alkaliborosilicate glasses under electron irradiation // Journal of Nuclear Materials. 2010. V. 396, № 2-3. Р. 264-271.

72. Малиновский В. К., Новиков В. Н., Соколов А. П. Низкочастотное комбинационное рассеяние в стеклообразных материалах // Физика и химия стекла. 1989. Т. 15, № 3. C. $331-344$.

73. Френкель Я. И. Кинетическая теория жидкостей. Ленинград: Наука, 1975. 592 с. 
74. Jenckel E. Zur Temperaturabhängigkeit der Viscosität von Schmelzen // Z. Phys. Chem. 1939. V. 184A, № 1. P. 309-319.

75. Meerlender G. Die erweiterte Jenckel-Gleichung, eine leistungsfähige Viskositätstemperature-formel. I, II // Rheol. Acta. 1967. V. 6, № 4. P. 309-377.

76. Bradbury D., Mark M., Kleinschmidt R. V. Viscosity and density of lubricating oils from 0 to 150000 Psig and 32 to 425 F // Trans. Amer. Soc. Mech. Eng. 1951. V. 73, № 5. P. 667-676.

77. Шишкин Н. И. Зависимость кинетических свойств жидкостей и стекол от температуры, давления и объема // ЖТФ. 1956. Т. 26, Вып. 7. С. 1461-1473.

78. Сандитов Д. С. Модель вязкого течения стеклообразующих жидкостей и стекол // ДАН. 2013. Т. 451, № 6. С. 650-654.

79. Сандитов Д. С. Поперечная деформация и нелинейность силы межатомного взаимодействия твердых тел // ДАН. 2019. Т. 486, № 1. С. 34-38.

80. Дунаев А. А., Борисова 3. У., Михайлов М. Д., Братов А. В. Синтез и свойства стекол системы мышьяк - теллур - алюминий // Физика и химия стекла. 1980. Т. 6, № 2. С. $174-178$.

81. Козлов Г. В., Сандитов Д. С. Ангармонические эффекты и физико-механические свойства полимеров. Новосибирск: Наука, 1994. 261 с.

82. Магафуров И. Ш., Тополкараев В. А., Маркарян Р. Е., Олейник Э. Ф. Восстановление размеров деформированных полимерных стекол под давлением // Высокомолек. соед. Сер. Б. 1991. Т. 32, № 2. С. 147-150.

83. Филянов Е. М. Активационные параметры пластической деформации и структура стеклообразных сетчатых полимеров // Высокомолек. соед. А. 1987. Т. 29, № 5. C. $975-982$.

84. Оптические стекла. Справочник / под ред. Г. Т. Петровского. Ленинград: ГОИ им С. И. Вавилова, 1975. 346 с.

Статья поступила в редакцию 24.11.2020; одобрена после рецензирования 28.01.2021; принята к публикации 29.01.2021.

\section{THE PLASTICITY EFFECT OF AMORPHOUS SUBSTANCES IN THE MODEL OF DELOCALIZED ATOMS}

Sanditov D. S.

Doctor of Physical and Mathematical Sciences, Professor

Buryat State University

670000, Ulan-Ude, Smolina str., 24a

Institute of Physical Materials Science SB RAS

670047, Ulan-Ude, ul. Sakhyanova, 6.

sanditov@bsu.ru

Abstract. Inorganic glasses, amorphous organic polymers and massive amorphous metal alloys (metallic glasses) exhibit a permanent deformation that persists for an arbitrarily long time at $20^{\circ} \mathrm{C}$. However, when heated below the glass transition temperature and near it, this deformation relaxes almost to disappearance. However, as a rule, the term "plastic deformation" is used for it. The nature of the plasticity effect of glasses remains not entirely clear, and is an unsolved problem. In general, the review is devoted to the discussion of the main regularities and the nature of plastic deformation of glassy solids and its thermally stimulated relaxation. Various interpretation options are considered. The mechanism and nature of this phenomenon are discussed in detail within the framework of the model 
Сандитов Д. С. Эффект пластичности стекол в модели делокализованных атомов

of delocalized atoms developed at the Dorzhi Banzarov Buryat State University and at the Institute of Physical Materials Science of the SB RAS.

Keywords: plasticity of glasses, thermally stimulated relaxation, glass transition, microhardness, atomic delocalization, computer simulation, nanoindentation, microdeformation of glasses.

For citation

Sanditov D. S. The Plasticity Effect of Amorphous Substances in the Model of Delocalized Atoms // Bulletin of Buryat State University. Chemistry. Physics. 2021; 1: 5-27 (In Russ.).

The article was submitted 24.11.2020; approved after reviewing 28.01.2021; accepted for publication 29.01.2021. 